\title{
Dialysis therapy, 2016 year in review 7. CKD-MBD
}

\author{
重松隆 小岩文彦 \\ 1和歌山県立医科大学腎臟内科学講座 \\ 2昭和大学藤が丘病院腎臟内科
}

\section{はじめに}

骨・ミネラル代謝障害 (chronic kidney diseasemineral and bone disorder: CKD-MBD) において 2016 年を中心に 1 年間の進歩と変遷について述べる. 特筆すべきことは 2 点で，国内では 2 凰目となる新し い calcimimetics（Ca 受容体作動薬）である etelcalcetide の臨床使用が可能となったこと．世界的には KDIGO (the Kidney Disease Improving Global Outcomes) の CKD-MBD ガイドラインが改訂になったこ とである。

\section{Etelcalcetide}

2017 年 2 月に世界に先駆けて国内で発売され，一般 臨床で使用が可能となった，本製剤は calcimimetics としては 2 郕めであり，初めての静注製剂である1). すでに2016年には治験が進んでおり，その結果が続々 と現在も報告されているところである。そのうち， Fukagawa らの 3 か月の論文を紹介する ${ }^{2)}$. 開始用量 は $5.0 \mathrm{mg} \times 3$ 回/week である. Intact-PTH のみなら ず，血清 $\mathrm{Ca}$ ・血清リン・骨吸収マーカー・血中 FGF23 のレベルをすべて低下させることが可能である．投薬 アドヒアランスは静注薬であり100\%である。すでに 1 年間の長期試験結果も Shigematsu らから報告され, 低 $\mathrm{Ca}$ 血症は効果発現の結果出現するが, 嘔気・嘔吐 などの消化器系の副作用の発現は少ない3)。ただし米 国からは cinacalcet との比較研究結果が報告され，嘔 気・嘔吐などの消化器系の副作用の両薬剤の発現頻度 には有意差がなかったとされる4).今後のわが国の実 臨床成績の蓄積が待たれる。

\section{KDIGO Clinical Practice Guideline of CKD-MBD}

まずは種々の上記ガイドラインには多バージョンが 存在するが, KDIGOのホームページで以下の URL 「http://kdigo.org/guidelines/ckd-mbd/」からアクセ スできるので試してほしい. 間に種々のコメントなど の動きがあったが, 前回のフルバージョンは2009年度 版5)であり, 実に 8 年ぶりの改訂である ${ }^{6)}$. 以下に筆者 が比較検討し 2009 年度版から変わったと感じたとこ ろを列記する。

1. CKD 患者の高齢化を反映し，骨粗鬆症を意識した 記述が増えた。特に dual-energy X-ray absorptiometry（DEXA）による骨密度測定を推奨するよ うになった。

2. 腎性骨症の治療方針決定には骨生検も有用である とし，若干であるが骨生検の意義が復活した。

3. Ca とリン・PTH に対する対応方針は基本は変わっ ていないと思われる，ただ微妙に言い回しの強さ が以下のように変わったようだ.

1）血清リン濃度は正常範囲を目指す。食事中リン 制限を評価し，特に添加物制限と植物性蛋白推 奨の姿勢が認められる。

2）高 $\mathrm{Ca}$ 血症は避けることは同様であるが, かなり 低 Ca 血症は容認姿勢となった。Ca 含有リン吸 着剂（炭酸 Ca）の使用はより制限する方向の記 述がなされている。

3）透析液 $\mathrm{Ca}$ 濃度は, 2.5〜3.0 mEq/L の間とするよ うに強調され，低 $\mathrm{Ca}$ 透析液の重点化のニュアン スが減弱した。ビタミン D 製剤の使用への消極 性の反映かもしれない.

4）二次性副甲状腺機能立進症治療には，Ca 受容体 拮抗薬の使用が全面に押し出されてきて，活性 型ビタミン D 製剤はどちらかというと Ca受容体

重松 隆 和歌山県立医科大学腎臓内科学講座％ $741-8510$ 和歌山県和歌山市紀三井寺 811-1

Takashi Shigematsu Tel：073-441-0638 Fax：073-441-0639 
表 1 血液透析患者における Lubiprostone 療法に伴う便性状と血清リン濃度の推移

\begin{tabular}{|c|c|c|c|c|c|c|c|}
\hline \multirow[t]{2}{*}{ Parameter } & \multirow{2}{*}{$\begin{array}{l}\text { Before treatment } \\
\quad \text { Mean } \pm \mathrm{SD}\end{array}$} & \multicolumn{2}{|l|}{ Month 1} & \multicolumn{2}{|l|}{ Month 2} & \multicolumn{2}{|l|}{ Month 3} \\
\hline & & Mean \pm SD & $\mathrm{p}$ value & Mean \pm SD & $\mathrm{p}$ value & Mean \pm SD & $\mathrm{p}$ value \\
\hline Stool frequency (times/month) & $1.8 \pm 1.3$ & $4.3 \pm 1.8$ & $\mathrm{p}<0.001$ & $4.9 \pm 1.9$ & $\mathrm{p}<0.001$ & $4.5 \pm 1.5$ & $\mathrm{p}<0.001$ \\
\hline Bristol Stool Form Scale & $2.3 \pm 1.0$ & $3.4 \pm 0.7$ & $\mathrm{p}<0.001$ & $3.5 \pm 0.8$ & $\mathrm{p}<0.001$ & $3.6 \pm 0.6$ & $\mathrm{p}<0.001$ \\
\hline Serum $\mathrm{Na}(\mathrm{mEq} / \mathrm{L})$ & $137.3 \pm 3.3$ & $137.5 \pm 3.0$ & $\mathrm{p}=0.963$ & $138.2 \pm 3.5$ & $\mathrm{p}=0.070$ & $138.2 \pm 4.0$ & $\mathrm{p}=0.180$ \\
\hline Serum $\mathrm{Cl}(\mathrm{mEq} / \mathrm{L})$ & $102.6 \pm 4.0$ & $103.0 \pm 3.0$ & $\mathrm{p}=0.434$ & $103.1 \pm 3.6$ & $\mathrm{p}=0.504$ & $103.0 \pm 3.2$ & $\mathrm{p}=0.743$ \\
\hline Serum $\mathrm{K} \quad(\mathrm{mEq} / \mathrm{L})$ & $4.4 \pm 0.7$ & $4.4 \pm 0.7$ & $\mathrm{p}=0.873$ & $4.3 \pm 0.6$ & $\mathrm{p}=0.415$ & $4.3 \pm 0.6$ & $\mathrm{p}=0.626$ \\
\hline Serum Ca $(\mathrm{mg} / \mathrm{dL})$ & $9.2 \pm 0.6$ & $9.1 \pm 0.6$ & $\mathrm{p}=0.159$ & $9.2 \pm 0.6$ & $\mathrm{p}=0.608$ & $9.2 \pm 0.6$ & $\mathrm{p}=0.499$ \\
\hline Serum IP (mg/dL) & $4.7 \pm 1.5$ & $4.5 \pm 1.6$ & $\mathrm{p}=0.123$ & $4.0 \pm 1.3$ & $\mathrm{p}<0.001$ & $3.8 \pm 1.1$ & $\mathrm{p}<0.001$ \\
\hline Geriatric nutritional risk index & $85.6 \pm 12.8$ & $85.4 \pm 11.9$ & $\mathrm{p}=0.501$ & $86.2 \pm 11.9$ & $\mathrm{p}=0.220$ & $86.4 \pm 11.1$ & $\mathrm{p}=0.061$ \\
\hline
\end{tabular}

$\mathrm{SE}$ : standrard deviation, $\mathrm{Na}$ : sodium, $\mathrm{Cl}$ : chloride, $\mathrm{K}$ : potassium, $\mathrm{Ca}$ : calcium, IP: inorganic phosphorus

（文献 11 より引用）

拮抗薬との併用療法が钊められている.

5）保存期 CKD 患者には，活性型ビタミン D 製剤は 二次性副甲状腺機能立進症治療を目的とする以 外は基本的には用いないこととされた.

6）腎移植患者においても骨粗鬆症の治療について 詳述されるようになった。

7）前回の 2009 年度版から変更はないが, 血中 25 $(\mathrm{OH}) \mathrm{D}$ の測定がかなり推奨され，ビタミン D 欠 そ症が骨粗鬆症との関係から意識されている. わが国では（活性型ではない）ビタミン D 製剤 は，薬品としての扱いはなくサプリメントとし て販売されている。ただ血中 $25(\mathrm{OH}) \mathrm{D}$ 測定が, クル病と骨軟化症と限られた対象疾患となって いるが保険診療として収載されたのは喜ばしい 動きである

\section{2016 年中心の日本発ならびに世界からの CKD-MBD 領域の業績}

わが国における CKD-MBD 領域の研究は世界的に みて, 最も活発に行われている領域である. 2016 年に おいても世界的にも評価されると思われる業績が多数 報告されている。そのうち筆者が論文を検索し得た中 から，好印象をもった論文をいくつか紹介する，ただ し繰り返しになるが，あくまでも能力の限られた検索 能力を有する個人の好み中心の選択であり，科学的な 普遍的価值と並行するほどの意義はないことを強調し ておく.

\section{1. リン吸着剂関連}

1）炭酸ランタンの治験 Phase III Study 開始後 8 年 以上観察できたわが国での症例がShigematsuら が，新しく創刊された日本透析医学会の公式欧 文誌（Renal Replacement Therapy 誌）に報告 している7)。これらの症例では危惧されていた肝
障害や血液障害などの副作用はなく, 8 年継続服 用例が示されている。 これは世界的にも長期投 与の報告である.

2） 2 番めの鉄含有リン吸着剤としての鉄含有リン 吸着剂：スクロオキシ水酸化鉄のわが国の HD 患者におけるデータが Koiwa らから報告されて いる ${ }^{8)}$. リン吸着力がかなり強く, 服用製剂数の 減薬が認められ有効性が高いと報告されてい $ろ^{9)}$.

3）すでにリン吸着剤として用いられている Ferric Citrate が, 経口鉄補給剤として評価され，腎性 貧血治療にもプラスになるとの米国の報告が Fishbane らからなされた ${ }^{10)}$.

4）下荗である lubiprostone が高リン血症を改善す る報告がわが国の Gen らからなされている，便 秘は高リン血症を悪化させ，下痢は血清リン值 を下げることは知られているが,「Lubiprostone, a novel laxative, might improve hyperphosphatemia without water dilution」と記載さ れており，便通に関係なく血清リン值を低下さ せるというユニークな報告である（表 1) ${ }^{11 ） . ~}$

\section{2. 食事療法関連}

1）添加物を減らすと血清リンコントロールが改善 する報告がブラジルからなされている，予想さ れた結果であるが，極めて困難と考えられる前 向きランダム化研究 (randomized controlled trial：RCT)できちんと証明されている. 今後の 添加物とリン関係の基本論文となり記憶すべき 論文と思われる12)。

\section{3. 血管石灰化関連}

1） warfarin 投与（Vit K 欠乏）は尿毒症性血管障害 のリスクである.すずに warfarin 投与は calciphylaxisのリスク因子として知られていたが, 透析療法導入時の種々因子を前向きに長期間観 


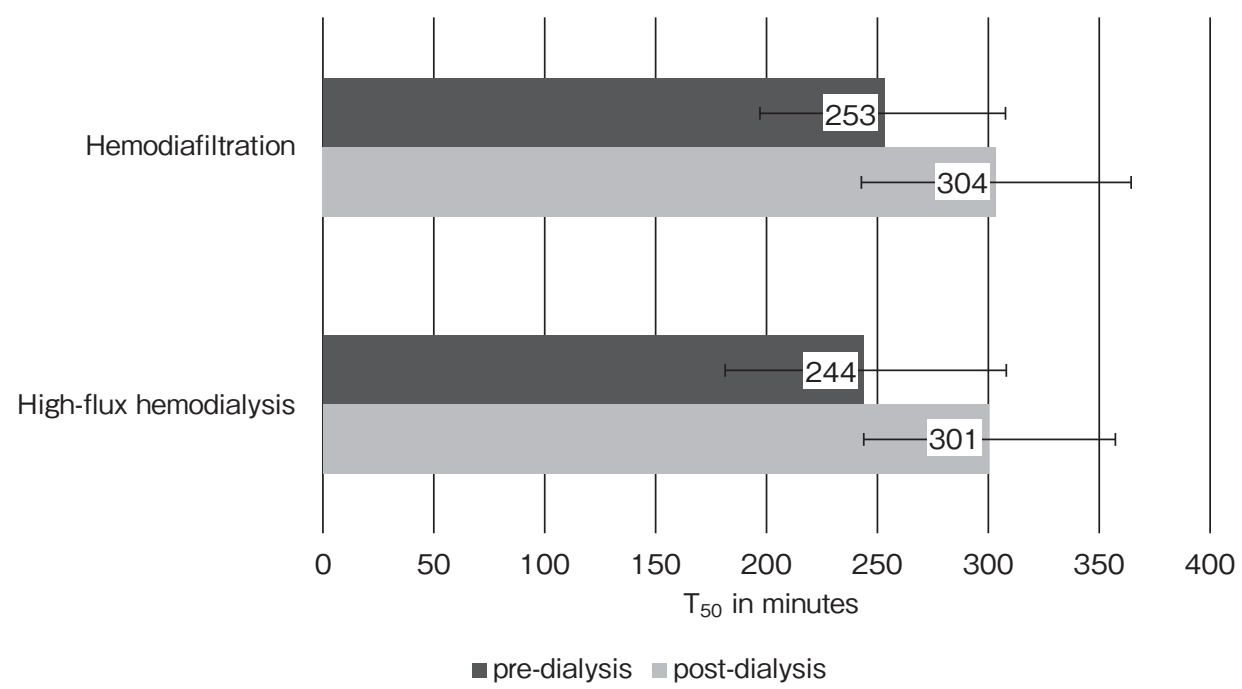

図 1 High-flux hemodialysis and high-volume hemodiafiltration により, 血管石灰化指数 (serum calcification propensity) が低下する. （文献 14 ょり引用）

察し, 二次性副甲状腺機能立進症や糖尿病より

も CKD 時代に服用していた warfarin が最も血 管障害の強い因子であることを厳密な統計結果 から記述した Nigwekar らの論文がある ${ }^{13)}$.

2）血管石灰化と透析 Modality の貴重な前向き論文 がDekker らから報告されている。このうち，

Pasch は, primary to secondary Calciprotein Particle (CPP) の転換点の指標である $\mathrm{T}_{50}$ test の提唱者で，この $\mathrm{T}_{50}$ を high-flux HD と highvolume HDF が低下させるとしている14) (図 1).

3） $T_{50}$ をblood calcification propensityとして, 前向 き 5 年間観察した研究でも, 心血管イベントと生 存率は $\mathrm{T}_{50}$ が高いほうが悪いことがPasch らが報 告している ${ }^{15)}$.

4）実験的に Mg 負荷が, リン負荷誘導性の血管中 膜石灰化を直接予防するという結果がSonou ら から血管培養 ex vivo 実験系から報告され, TRPM7 と Pit-1 が血管中膜石灰化進展に関与し ていることが画像的にも成分分析からも証明さ れている16).

\section{おわりに}

CKD-MBD 領域は骨代謝領域・腎臟病領域・血液浄 化領域・循環器領域のいずれも中心命題ではなく傍流 領域である。しかしながら, 生命予後にも関係し CKD-MBD として注目を集め, 薬物療法を始め病態生 理や疫学研究など多くの論文が報告されている. 今 回, 紹介できたのはほんの一部にしかすぎない. 本項
が読者の興味と関心の一助になれば幸いである.

\section{文献}

1) Yokoyama K, Fukagawa M, Shigematsu T, et al. A 12-week dose-escalating study of etelcalcetide (ONO-5163/AMG 416), a novel intravenous calcimimetic, for secondary hyperparathyroidism in Japanese hemodialysis patients. Clin Nephrol 2017; 88: 68-78.

2) Fukagawa M, Yokoyama K, Shigematsu T, et al; ONO-5163 Study Group: A phase 3, multicentre, randomized, double-blind, placebo-controlled, parallel-group study to evaluate the efficacy and safety of etelcalcetide (ONO-5163/AMG 416), a novel intravenous calcimimetic, for secondary hyperparathyroidism in Japanese haemodialysis patients. Nephrol Dial Transplant 2017; 32: 1723-30.

3) Shigematsu T, Fukagawa M, Yokoyama K, et al; ONO-5163 Study Group. Long-term effects of etelcalcetide as intravenous calcimimetic therapy in hemodialysis patients with secondary hyperparathyroidism. Clin Exp Nephrol 2017; Aug 23. Doi: 10.1007/s10157-017-1442-5.

4) Block GA, Bushinsky DA, Cheng S, et al. Effect of Etelcalcetide vs Cinacalcet on Serum Parathyroid Hormone in Patients Receiving Hemodialysis With Secondary Hyperparathyroidism: A Randomized Clinical Trial. JAMA 2017; 317: 156-64.

5) Kidney Disease: Improving Global Outcomes (KDIGO) CKD-MBD Work Group. KDIGO clinical practice guideline for the diagnosis, evaluation, prevention, and treatment of Chronic Kidney DiseaseMineral and Bone Disorder (CKD-MBD). Kidney Int 
Suppl. 2009; 113: S1-130.

6) Ketteler M, Block GA, Evenepoel P, et al. Executive summary of the 2017 KDIGO Chronic Kidney Disease-Mineral and Bone Disorder (CKD-MBD) Guideline Update: what's changed and why it matters. Kidney Int 2017; 92: 26-36.

7) Shigematsu T, Negi S, Ohya M. Long-term observational study in Japanese hemodialysis patients who completed a 3-year clinical study of lanthanum carbonate. Ren Replace Ther 20162: 30, doi. org/ 10.1186/s41100-016-0040-4

8) Koiwa F, Terao A. Dose-response efficacy and safety of PA21 in Japanese hemodialysis patients with hyperphosphatemia: a randomized, placebo-controlled, double-blind, Phase II study. Clin Exp Nephrol 2017; 21: 513-22.

9) Koiwa F, Yokoyama K, Fukagawa M, Terao A, Akizawa T. Efficacy and safety of sucroferric oxyhydroxide compared with sevelamer hydrochloride in Japanese haemodialysis patients with hyperphosphataemia: A randomized, open-label, multicentre, 12week phase III study. Nephrology (Carlton). 2017; 22: 293-300.

10) Fishbane S, Block GA, Loram L, et al. Effects of Ferric Citrate in Patients with Nondialysis-Dependent CKD and Iron Deficiency Anemia. J Am Soc Nephrol
2017; 28: 1851-8.

11) Gen S, Nobe K, Ikeda N. Lubiprostone, a novel laxative, might improve hyperphosphatemia without water dilution. Ren Replace Ther 2016; 2: 50.

12) de Fornasari ML, Dos Santos Sens YA. Replacing Phosphorus-Containing Food Additives With Foods Without Additives Reduces Phosphatemia in EndStage Renal Disease Patients: A Randomized Clinical Trial. J Ren Nutr 2017; 27: 97-105.

13) Nigwekar SU, Zhao S, Wenger J, et al. A Nationally Representative Study of Calcific Uremic Arteriolopathy Risk Factors. J Am Soc Nephrol 2016; 27: 3421-9.

14) Dekker M, Pasch A, van der Sande F, et al. HighFlux Hemodialysis and High-Volume Hemodiafiltration Improve Serum Calcification Propensity. PLoS One 2016; 11: e0151508.

15) Pasch A, Block GA, Bachtler M, et al. Blood Calcification Propensity, Cardiovascular Events, and Survival in Patients Receiving Hemodialysis in the EVOLVE Trial. Clin J Am Soc Nephrol 2017; 12: 315-22.

16) Sonou T, Ohya M, Yashiro M, et al. Magnesium prevents phosphate-induced vascular calcification via TRPM7 and Pit-1 in an aortic tissue culture model. Hypertens Res 2017； 40: 562-7. 